\title{
PENGARUH PENAMBAHAN NATRIUM METABISULFIT DAN SUHU PEMASAKAN DENGAN MENGGUNAKAN TEKNOLOGI VAKUM TERHADAP KUALITAS GULA MERAH TEBU
}

\author{
Influences of Sodium Metabisulphite and Evaporation Vacuum Temperature on Brown Sugar Cane Quality \\ Dewi Maya Maharani, Rini Yulianingsih, Shinta Rosalia Dewi, Yusron Sugiarto, Dina Wahyu Indriani
}

Jurusan Keteknikan Pertanian, Fakultas Teknologi Pertanian, Universitas Brawijaya, Jl. Veteran, Malang 65145

Email: maya_maharani@ub.ac.id

\begin{abstract}
ABSTRAK
Gula merah sebagai sukrosa diperoleh dari nira tebu yang diuapkan. Penguapan merupakan proses pengolahan bahan pangan yang umumnya digunakan pada pembuatan gula merah tebu, dimana proses ini menguapkan sebagian besar nira untuk menghasilkan produk yang kental (konsentrat). Penelitian ini bertujuan untuk mengkaji pengaruh penambahan natrium metabisulfit terhadap sifat fisik dan kimia gula merah tebu yang dihasilkan dari penggunaan vacuum evaporator, dan mengkaji pengaruh suhu pemasakan pada vacuum evaporator terhadap sifat fisik dan kimia gula merah tebu. Pemasakan gula dilakukan pada tekanan $-700 \mathrm{mmHg}$ di bawah tekanan atmosfir, dengan variasi suhu pemasakan 60,70 dan $80^{\circ} \mathrm{C}$ dan dengan penambahan natrium metabisulfit 0,$1 ; 0,3$ dan $0,5 \mathrm{~g} / 1$ nira. Semakin besar penambahan natrium metabisulfit dalam pengolahan gula merah tebu, semakin tinggi kadar abu yang dihasilkan sedangkan intensitas warna hijau dan biru gula merah tebu semakin kecil. Semakin tinggi suhu pemasakan, semakin rendah kadar air, kadar abu, intensitas warna hijau dan biru gula merah tebu. Semakin tinggi suhu pemasakan, semakin tinggi tingkat kekerasan atau tekstur, tingkat kesukaan warna, rasa dan tekstur gula merah tebu. Berdasarkan analisis statistik, perlakuan suhu pemasakan berpengaruh terhadap kadar air, kadar abu dan gula reduksi gula merah tebu. Sedangkan perlakuan penambahan natrium metabisulfit berpengaruh terhadap kadar abu, gula reduksi dan total padatan tak terlarut pada gula merah tebu. Berdasarkan parameter sifat kimia, fisik, uji organoleptik dan persyaratan SNI gula merah tebu, penambahan natrium metabisulfit $0,3 \mathrm{~g} / 1$ dan suhu pemasakan $80^{\circ} \mathrm{C}$ dalam pengolahan nira tebu menjadi gula merah menunjukkan kualitas yang paling baik. Nilai masing-masing parameternya dari perlakuan terbaik sebagai berikut: parameter kimia dan fisik dengankadar air 8,97\%, gula reduksi 7,96\%, kadar abu 2,65\%, total padatan tak larut $0,60 \%$, nilai kekerasan $15,68 \mathrm{~kg} / \mathrm{cm}^{2}$, parameter organoleptik denganwarna 5,50, rasa 5,04 dan tekstur 5,36.
\end{abstract}

Kata kunci: Nira tebu, natrium metabisulfit, suhu, evaporator vakum, gula merah

\begin{abstract}
Brown sugar as sucrose is derived from evaporated sugar cane molasses. Evaporation is the foodstuffs' process which is commonly used during the manufacture of sugar cane. This process evaporates the sugar cane molasses to produce concentrate. This research was aimed to assess the influence of sodium metabisulphite against physical and chemical properties of sugar cane using vacuum evaporator. In other hand, this reserach examined the influence of temperature on vacuum evaporator for chemical and physical properties of sugar cane. Sugar cooking was done at $-700 \mathrm{mmHg}$ below atmospheric pressure, with variations in heating temperature of 60,70 and $80^{\circ} \mathrm{C}$, and with the addition of sodium metabisulphite $0.1 ; 0.3$ and $0.5 \mathrm{~g} / 1$ sugar cane molasses. The larger addition of sodium metabisulphite in the processing of sugar cane, the higher ash content generated while the green and blue colors of red sugar cane were getting smaller. The higher cooking temperature, the lower the moisture content, ash content, color intensity of red, green and blue of sugar cane. The higher the cooking temperature, the higher the degree of hardness or texture, color preference level, the taste and texture of sugar cane. Based on statistical analysis, cooking temperature affects the moisture content, ash, and the reduction sugar of cane brown sugar. While the addition of sodium metabisulfite gives effects on ash, reduction sugar and the total dissoluble solids of sugar cane. Based on the parameters of chemical properties, physical, organoleptic tests and SNI requirements of sugar cane, the addition of sodium metabisulphite variation of $0.3 \mathrm{~g} / \mathrm{l}$ and a heating temperature of $80^{\circ} \mathrm{C}$ in processing sugar cane into brown sugar have shown the most excellent quality. The value of each parameter based on the best treatments as follows: chemical and physical parameters with $8.97 \%$ of water
\end{abstract}


content, $8.29 \%$ of reduction sugar, $0.96 \%$ of ash content, $0.50 \%$ of total dissoluble solid, $15.68 \mathrm{~kg} / \mathrm{cm} 2$ of hardness value, while for organoleptic parameters for color 5.50, flavor 5.04 and texture 5.36.

Keywords: Sugar cane molasses, sodium metabisulphite, temperature, vacuum evaporator, brown sugar

\section{PENDAHULUAN}

Gula merupakan komoditi strategis karena dikonsumsi oleh seluruh lapisan masyarakat. Pada tahun 2014 kebutuhan gula nasional mencapai 5,700 juta ton (Kementan, 2013). Salah satu jenis gula yang dibutuhkan oleh masyarakat umum adalah gula merah. Potensi pasar gula merah tebu diperbesar oleh industri makanan misalnya di Jawa Timur dari kebutuhan sebesar 30-40 ribu ton per tahun, petani hanya bisa memenuhi kebutuhan produksi sekitar 5 ribu ton (Rosdiansyah 2012 dalam Darma dkk., 2012). Pada tahun 2013, konsumsi ratarata gula merah per kapita seminggu mencapai 0,105 ons (Kementan, 2013). Peran gula merah tidak dapat digantikan oleh jenis lain karena memiliki sifat-sifat spesifik dan rasa yang khas yaitu manis, asam dan berbau karamel. Rasa karamel pada gula merah diduga disebabkan adanya reaksi karamelisasi akibat pemanasan selama pemasakan. Karamelisasi juga menyebabkan timbulnya warna coklat pada gula merah (Nurlela, 2002). Keunggulan yang dimiliki gula merah adalah adanya galaktomanan, tersedianya energi spontan yaitu energi yang dapat dimanfaatkan langsung oleh tubuh, antioksidan, dan mengandung senyawa non gizi yang bermanfaat bagi penderita diabetes (Narulita, 2008).

Selain harus memenuhi kebutuhan dalam negeri, gula merah tebu juga memiliki potensi ekspor sehingga akan menguntungkan industri gula merah tebu. Gula merah tebu yang berhasil masuk ke pasar internasional harus memenuhi standar mutu yang telah ditetapkan. Kualitas gula merah tebu di Indonesia dapat dikatakan masih rendah dikarenakan pengolahannya masih tradisional dimana proses penguapan nira belum disertai dengan pengontrolan suhu bahan. Pengontrolan suhu yang kurang baik dapat menyebabkan terjadinya karamelisasi dan kualitas produk akhir tidak terjaga dengan baik. Oleh karena itu, dalam penelitian ini dilakukan penggembangan teknologi pengolahan gula merah dengan menggunakan teknologi vakum yang disertai beberapa pengontrolan suhu bahan selama pemasakan atau evaporasi. Selain itu, perlu dilakukan pengkajian terhadap penambahan natrium metabisulfit dan suhu pemasakan yang akan mempengaruhi parameter penentu kualitas gula merah tebu.

\section{METODE PENELITIAN}

\section{Bahan dan Alat}

Bahan yang digunakan dalam penelitian adalah nira tebu, kapur tohor, akuades, gas LPG, kertas pH. Nira diambil dari tebu yang sudah mendekati umur kematangan di daerah Merjosari, Malang. Alat-alat yang digunakan adalah kain saring untuk menyaring nira tebu dari kotoran, vacuum evaporator, stopwatch digital, corong, pengaduk, timbangan analitik, pencetak, wadah bahan (panci), cawan petri, gelas ukur, desikator, oven, inkubator, color analyzer untuk pengujian warna, dan texture analyser untuk pengujian tekstur (kekerasan).

\section{Jalannya Penelitian}

Tahap pendahuluan digunakan untuk mengetahui lamanya pemasakan optimal pada vacuum evaporator pada perlakuan yang diterapkan. Perlakuan tersebut yaitu penambahan natrium metabisulfit dan suhu pemasakan. Penelitian utama dilakukan dengan tahapan seperti terdapat Gambar 1. Setelah itu dilakukan pengujian parameter mutu antara lain kadar air (AOAC, 1995), gula reduksi (BSN, $\left.1992^{2}\right)$, kadar abu (BSN, 1992'), total padatan tak terlarut $\left(\mathrm{BSN}, 1992^{1}\right)$, warna dan tekstur. Selain itu dilakukan pengujian hedonik untuk mengetahui tingkat kelayakan

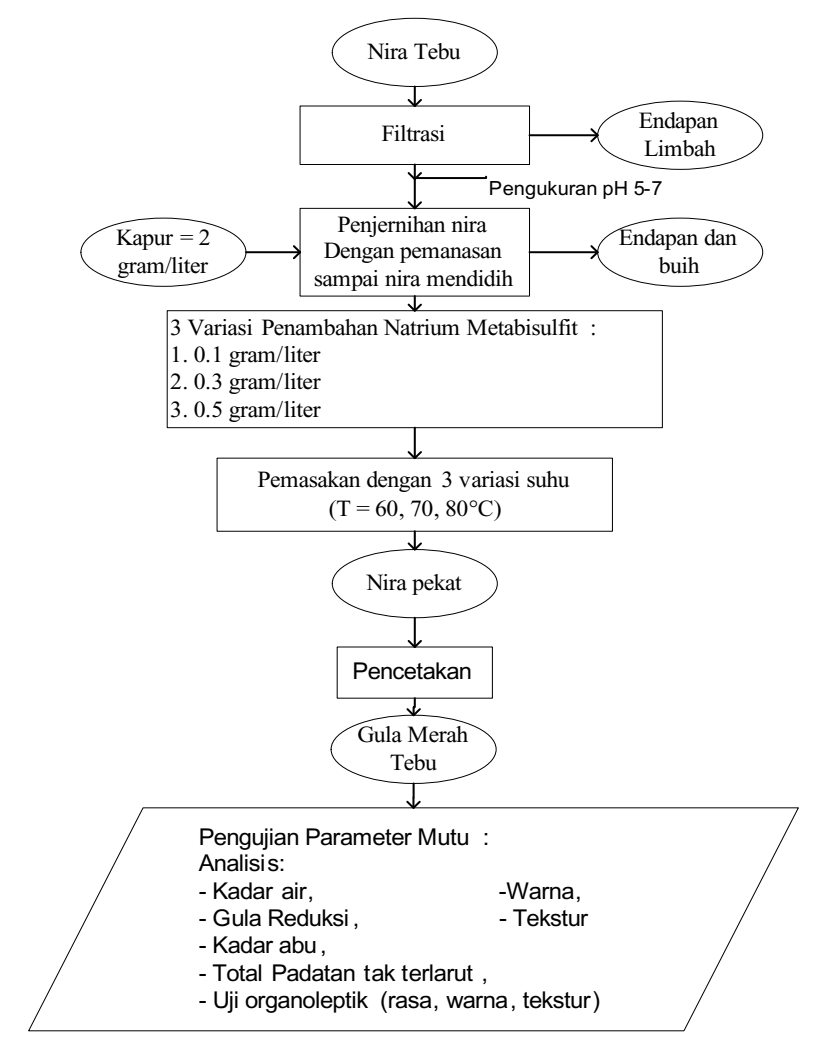

Gambar 1. Diagram alir penelitian pengaruh natrium metabisulfit dan suhu pemasakan 
suatu bahan agar dapat diterima oleh konsumen. Uji tingkat kesukaan ini meliputi uji rasa, warna, dan tekstur. Skor yang digunakan adalah dari angka 1 sampai 7. Selain itu juga dilakukan penilaian perlakuan terbaik (1-8).

\section{HASIL DAN PEMBAHASAN}

Dari penelitian pendahuluan didapatkan waktu pemasakan optimal pengolahan nira sampai menjadi gula siap cetak pada perlakuan yang diterapkan. Waktu pemasakan pada masing-masing variasi penambahan natrium metabisulfit dan suhu pemasakan terdapat dalam Tabel 1.

Tabel 1. Waktu pemasakan

\begin{tabular}{lccc}
\hline \multirow{2}{*}{$\begin{array}{l}\text { Penambahannatrium } \\
\text { metabisulfit }(\mathrm{g} / \mathrm{l})\end{array}$} & \multicolumn{3}{c}{ Suhu pemasakan $\left({ }^{\circ} \mathrm{C}\right)$} \\
\cline { 2 - 4 } 0,1 & 130 menit & 144 menit & 133 menit \\
0,3 & 105 menit & 93 menit & 94 menit \\
0,5 & 99 menit & 94 menit & 93 menit \\
\hline
\end{tabular}

Selanjutnya penelitian utama dilakukan dengan menguapkan nira tebu sesuai hasil penelitian pendahuluan (Tabel 1). Sebelum berlangsung proses evaporasi, dilakukan pengukuran $\mathrm{pH}$ awal pada hasil fitrasi nira tebu. Hasil pengukuran menunjukkan bahwa nira tebu memiliki $\mathrm{pH} 6$ untuk semua variasi perlakuan. Sehingga dapat disimpulkan bahwa nira layak digunakan untuk pembuatan gula merah tebu.

\section{Brix Nira}

Hasil pengukuran nilai brix sebelum dan sesudah evaporasi pada variasi penambahan natrium metabisulfit dan suhu pemasakan dapat dilihat pada Gambar 2.

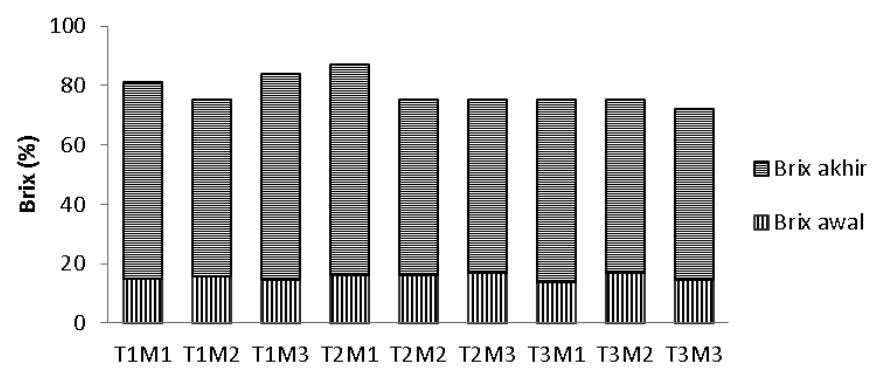

Gambar 2. Brix nira sebelum dan sesudah evaporasi

Pada Gambar 2 terlihat bahwa brix nira sebelum evaporasi berkisar antara 15 $\pm 2 \%$. Menurut Rakhmadiono (1995), standar brix nira yang baik untuk diolah menjadi gula adalah $>16 \%$. Brix nira yang berada dibawah $16 \%$ menunjukkan bahwa nira mengalami kerusakan. Kerusakan nira dapat terjadi karena kontaminasi mikroba dan nira mengalami fermentasi menjadi asam, berbuih, dan berlendir. Fermentasi nira disebabkan karena adanya bakteri dan khamir.

Proses pemasakan atau evaporasi dilakukan hingga bahan memiliki Brix 72\% hingga 87\%. Gula merah tebu yang diolah secara manual atau tanpa evaporator vakum memiliki nilai brix sebesar 86,64\% (bb) (Yustiningsih, 2006). Dari hasil penelitian pengolahan gula merah tebu baik menggunakan maupun tanpa evaporator vakum telah sesuai dengan syarat brix mutu I dari SNI 01-6237-2000 yaitu minimal 65\% (bb). Pembuatan gula cetak membutuhkan titik kondisi dimana dalam melakukan pemberhentian proses evaporasi harus tepat dan bahan hanya mengandung sedikit air. Kondisi yang tidak tepat akan mengakibatkan gagalnya pencetakan.

\section{Kadar Air}

Kadar air gula merah tebu yang dihasilkan sebesar 8,3\% untuk perlakuan penambahan natrium metabisulfit $0,1 \mathrm{~g} / 1$ pada suhu $80^{\circ} \mathrm{C}$ dan $12,9 \%$ pada penambahan $0,3 \mathrm{~g} / 1$ dengan suhu $60^{\circ} \mathrm{C}$. Semakin tinggi suhu pemasakan yang digunakan, semakin besar air nira yang diuapkan sehingga terjadi penurunan kadar air bahan. Hasil secara lengkap terdapat pada Gambar 3.

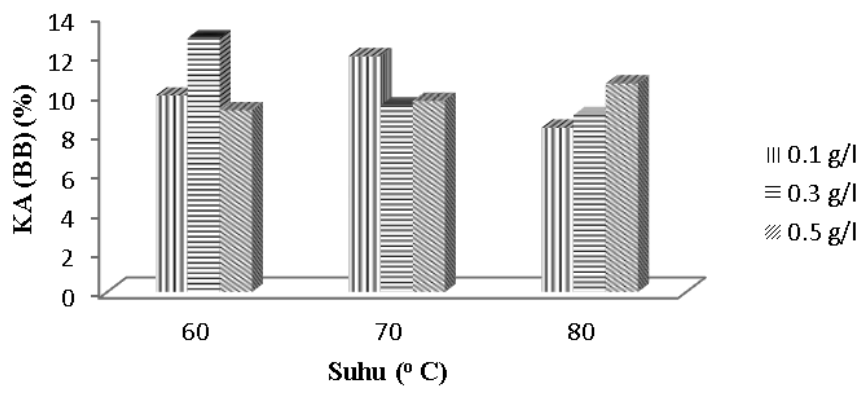

Gambar 3. Kadar air gula merah tebu pada variasi penambahan natrium metabisulfit dan suhu pemasakan

Kadar air yang terkandung dalam gula merah akan mempengaruhi tekstur gula, dimana semakin tinggi kadar air akan mengakibatkan turunnya tingkat kekerasan gula dan mempersingkat daya simpan (Dachlan dalam Yustiningsih, 2006). Kadar air gula merah tebu, selain dipengaruhi oleh waktu pemasakan juga dipengaruhi oleh kadar gula pereduksi dan kondisi lingkungan. Kadar air akan semakin tinggi dengan semakin tingginya kandungan gula pereduksi, khususnya fruktosa. Fruktosa bersifat higroskopis, sehingga dapat dengan mudah menyerap air. Kelembaban lingkungan yang tinggi akan meningkatkan penyerapan uap air oleh gula sehingga terjadi peningkatan kandungan kadar air dan penurunan tekstur (Sudarmadji dalam Yustiningsih, 2006).

Menurut SNI 01-6237-2000 yang dikeluarkan oleh Badan Standarisasi Nasional (BSN), syarat kadar air gula merah adalah maksimal 10\%. Gula merah tebu yang diolah 
secara manual atau tanpa evaporator vakum memiliki kadar air sebesar 6,29\% (Yustiningsih, 2006). Dari hasil pengolahan gula merah tebu secara manual atau tanpa evaporator vakum telah sesuai dengan SNI. Sedangkan hasil penelitian ini dapat dilihat pada Gambar 3 yang menunjukkan bahwa terdapat beberapa perlakuan yang memiliki nilai kadar air yang lebih tinggi dari standar yang sudah ditetapkan. Hal ini disebabkan karena pengecekan tingkat kematangan gula merah yang sedikit mengalami kendala ketika pemrosesan dilakukan secara vakum.

Berdasarkan analisis Anova dengan keseragaman pada taraf nyata 5\% dan 1\% menggunakan excel, faktor suhu pemasakan memberikan pengaruh yang sangat nyata terhadap kadar air akhir gula merah tebu maka selanjutnya dilakukan uji BNT. Dari pengujian tersebut diperoleh bahwa hasil notasi yang sama pada setiap perlakuan. Hal ini berarti bahwa tidak ada perbedaan yang signifikan untuk setiap variasi perlakuan suhu baik 60,70 dan $80^{\circ} \mathrm{C}$ terhadap kadar air gula merah tebu. Sedangkan pada variasi penambahan natrium metabisulfit, diperoleh nilai $\mathrm{F}$ hitung lebih kecil dari F tabel. Nilai F hitung $<$ F tabel 5\% dan 1\% menunjukkan tidak terdapat perbedaan yang nyata. Hal ini berarti bahwa faktor penambahan natrium metabisulfit tidak memberikan pengaruh yang nyata terhadap kadar air akhir gula merah tebu. Hasil yang tidak berpengaruh nyata ini disebabkan karena kadar air akhir gula merah pada beberapa variasi penambahan natrium metabisulfit nilainya hampir sama. Data pengamatan tetap terlihat ada perbedaan, tetapi Anova tidak mampu mendeteksi perbedaan nilai tersebut.

\section{Tekstur}

Tekstur merupakan salah satu parameter penting dalam menentukan mutu gula merah tebu. Pengaruh perlakuan penambahan natrium metabisulfit dan suhu pemasakan terhadap tekstur gula merah tebu terdapat pada Gambar 4.

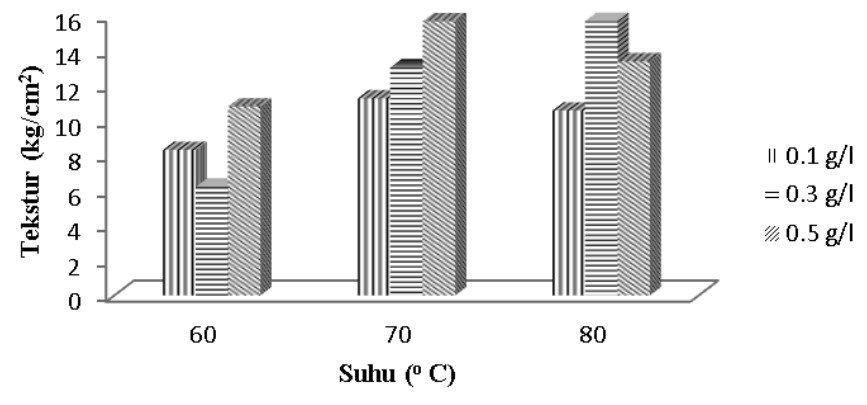

Gambar 4. Tekstur gula merah tebu pada variasi penambahan natrium metabisulfit dan suhu pemasakan

Gambar 4 memperlihatkan bahwa secara umum, perlakuan suhu yang tinggi menghasilkan tekstur yang lebih tinggi juga, sedangkan penambahan natrium metabisulfit tidak memberikan pengaruh yang nyata. Tekstur gula terlunak terdapat pada perlakuan suhu $60^{\circ} \mathrm{C}$ dengan penambahan natrium metabisulfit $0,3 \mathrm{~g} / 1$, sedangkan tekstur tertinggi pada perlakuan suhu $80^{\circ} \mathrm{C}$ dengan penambahan $0,3 \mathrm{~g} / \mathrm{l}$. Semakin tinggi suhu pemasakan, semakin besar air yang teruapkan sehingga kadar air semakin rendah. Kadar air yang rendah menghasilkan tekstur yang lebih keras. Hal ini sesuai dengan Sudarmadji dkk. (1989) yang mengatakan bahwa semakin lama pemasakan akan menghasilkan kadar air yang semakin rendah dan kadar air yang semakin rendah akan menghasilkan tekstur yang lebih keras.

Tekstur gula dipengaruhi oleh beberapa faktor yaitu kualitas nira, kadar air, kadar lemak serta kandungan pektin dan protein. Nira yang berkualitas bagus memiliki kandungan sukrosa yang tinggi, dan gula merah yang dihasilkan akan memiliki tekstur yang baik. Nira yang telah terfermentasi mengandung gula pereduksi yang tinggi, dimana ini akan menyebabkan gula memiliki sifat higroskopis sehingga daya simpan rendah. Jumlah protein dan pektin yang tinggi akan menyebabkan gula menjadi lebih lembek (Firmansyah, 1992). Menurut Santoso dkk. (1993) dalam Dyanti (2002) molekul-molekul lemak di dalam gula merah membentuk globula-globula yang menyebar diantara kristal atau butiran gula, sehingga menyebabkan kekerasan gula berkurang.

\section{Kadar Abu}

Proses penjernihan nira menggunakan kapur $\left(\mathrm{Ca}(\mathrm{OH})_{2}\right.$ dan variasi penambahan natrium metabisulfit akan menghasilkan sisa kandungan $\mathrm{Ca}$. Kadar abu total dalam gula merah tebu sebagai parameter kandungan Ca. Pengaruh perlakuan penambahan natrium metabisulfit dan suhu pemasakan terhadap kadar abu gula merah tebu terdapat pada Gambar 5.

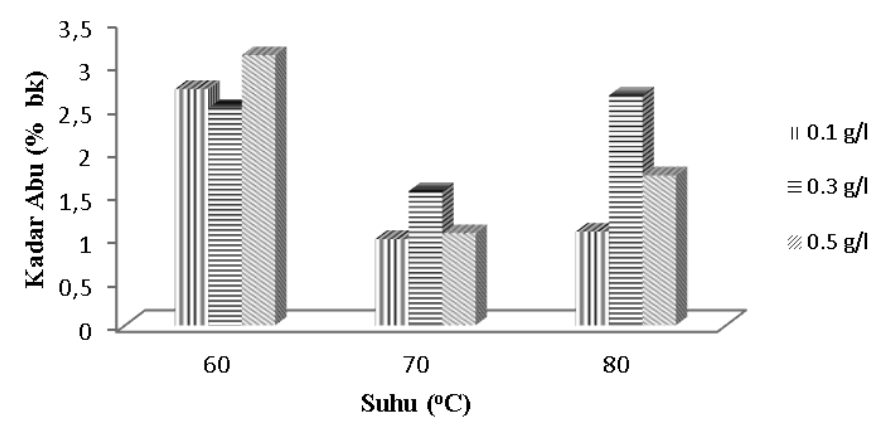

Gambar 5. Kadar abu gula merah tebu pada variasi penambahan natrium metabisulfit dan suhu pemasakan

Menurut SNI 01-3743-1995, syarat kadar abu gula merah adalah maksimal $2 \%$ bb. Gula merah tebu yang diolah secara manual atau tanpa evaporator vakum memiliki kadar abu sebesar 0,83\% (Yustiningsih, 2006). Dari hasil pengolahan gula merah tebu secara manual atau tanpa evaporator vakum 
telah sesuai dengan SNI. Sedangkan hasil pengolahan gula merah tebu menggunakan evaporator vakum dapat dilihat pada Gambar 5 yang menunjukkan bahwa kadar abu berkisar $1-3,11 \%$ bk. Kadar abu yang tertinggi dan lebih besar dari SNI adalah pada perlakuan dengan penambahan natrium metabisulfit $0,5 \mathrm{~g} / 1$ pada suhu pemasakan $60^{\circ} \mathrm{C}$ yaitu sebesar $3,11 \%$. Dengan melakukan pemasakan dengan suhu yang lebih tinggi maka didapatkan kadar abu yang relatif lebih rendah. Pada suhu $60^{\circ} \mathrm{C}$, kadar abu lebih tinggi karena total disoluble solid (TDS) tinggi. Dengan adanya penambahan suhu $70^{\circ} \mathrm{C}$, terjadinya penurunan kadar abu karena kecenderungan penurunan TDS. Apabila suhu ditingkatkan lebih tinggi lagi maka menyebabkan kotoran bukan gula akan muncul dan meningkatkan kadar abu. Sehingga didapakan kesimpulan bahwa suhu $70^{\circ} \mathrm{C}$ merupakan suhu optimum untuk menghasilkan kadar abu yang rendah. Gambar 5 juga menunjukkan bahwa semakin besar penambahan natrium metabisulfit maka kadar abu cenderung semakin tinggi. Hal ini dikarenakan kadar abu yang terhitung dalam gula merah adalah kandungan natrium metabisulfit dan mineral lain seperti kapur untuk penjernihan nira tebu. Hasil penelitian yang dilakukan Lesthari (2006) juga menyimpulkan bahwa penambahan natrium metabisulfit akan meningkatkan kadar abu.

Berdasarkan analisis Anova didapatkan bahwa suhu pemasakan dan penambahan natrium metabisulfit memberikan pengaruh yang nyata terhadap kadar abu gula merah tebu. Rerata kadar abu hasil uji BNT dapat dilihat pada Tabel 2 dan Tabel 3.

Tabel 2. Rerata kadar abu (\%) gula merah tebu akibat perlakuan suhu

\begin{tabular}{lll}
\hline Suhu $\left({ }^{\circ} \mathrm{C}\right)$ & Rerata kadar abu $(\%)$ & BNT 5\% \\
\hline 60 & $2,487^{\mathrm{c}}$ & \\
70 & $1,079^{\mathrm{a}}$ & 0,1361269 \\
80 & $1,650^{\mathrm{b}}$ & \\
\hline
\end{tabular}

Tabel 3. Rerata kadar abu (\%) gula merah tebu akibat penambahan natrium metabisulfit

\begin{tabular}{ccc}
\hline $\begin{array}{c}\text { Natrium } \\
\text { metabisulfit }(\mathrm{g} / \mathrm{l})\end{array}$ & $\begin{array}{c}\text { Rerata kadar abu } \\
(\%)\end{array}$ & BNT 5\% \\
\hline 0,1 & $1,440^{\mathrm{a}}$ & \\
0,3 & $1,998^{\mathrm{c}}$ & 0,1361269 \\
0,5 & $1,778^{\mathrm{b}}$ & \\
\hline
\end{tabular}

\section{Gula Reduksi}

Pengaruh perlakuan penambahan natrium metabisulfit dan suhu pemasakan terhadap gula reduksi gula merah tebu terdapat pada Gambar 6.

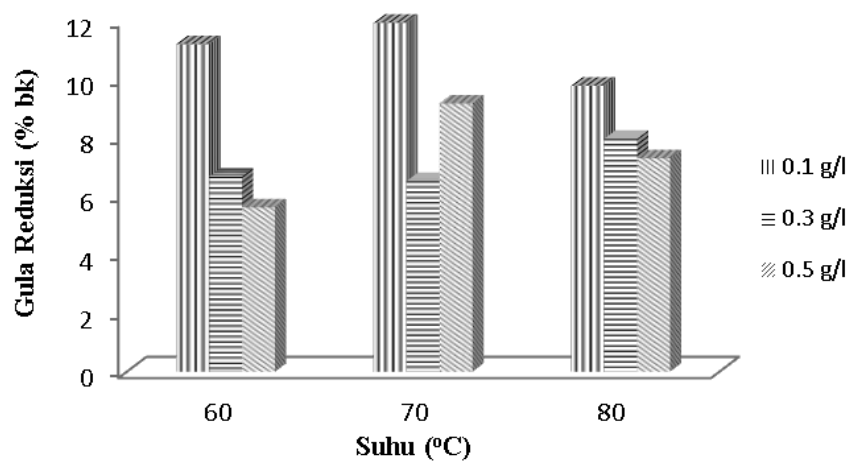

Gambar 6. Gula reduksi gula merah tebu pada variasi penambahan natrium metabisulfit dan suhu pemasakan

Kadar sukrosa yang tinggi disertai kadar glukosa yang rendah menggambarkan gula bermutu tinggi. Pada Gambar 6 menunjukkan bahwa dengan menggunakan evaporator vakum didapatkan hasil kadar gula reduksi tertinggi sebesar $11,94 \%$ pada penambahan natrium metabisulfit $0,1 \mathrm{~g} / 1$ pada suhu $70 \%$. Sedangkan pada perlakuan penambahan natrium metabisulfit $0,5 \mathrm{~g} / 1$ dengan pemanasan $60^{\circ} \mathrm{C}$ memiliki kandungan gula reduksi sebesar 5,62\%. Hasil pengolahan gula merah tebu secara manual atau tanpa evaporator vakum memiliki kadar gula reduksi sebesar 2,74\% (Yustiningsih, 2006). Menurut SNI 01-6237-2000 yang dikeluarkan oleh Badan Standarisasi Nasional (BSN), syarat gula reduksi gula merah Mutu I adalah maksimal $11 \%$ bb. Gula reduksi gula merah tebu baik diolah menggunakan maupun tanpa evaporator vakum telah sesuai dengan pesyaratan SNI. Kandungan gula pereduksi yang tinggi pada nira menyebabkan gula yang dihasilkan menjadi lembek dan bersifat higroskopis. Rendahnya kadar sukrosa dan tingginya kadar glukosa dalam produk gula dapat disebabkan oleh mutu tebu yang rendah atau proses pengolahan yang kurang baik.

Berdasarkan hasil analisis ragam menunjukkan bahwa faktor suhu pemasakan dan penambahan natrium metabisulfit memberikan pengaruh yang sangat nyata terhadap kadar gula reduksi. Kedua faktor ini kemudian dilakukan pengujian BNT dengan taraf 5\%. Nilai rerata gula reduksi hasil uji BNT dapat dilihat pada Tabel 4 dan 5.

Tabel 4. Rerata gula reduksi (\%) gula merah tebu akibat perlakuan suhu

\begin{tabular}{lll}
\hline Suhu $\left({ }^{\circ} \mathrm{C}\right)$ & Rerata gula reduksi $(\%)$ & BNT 5\% \\
\hline 60 & $7,000^{\mathrm{a}}$ & \\
70 & $8,233^{\mathrm{c}}$ & 0,2324729 \\
80 & $7,621^{\mathrm{b}}$ & \\
\hline
\end{tabular}


Tabel 5. Rerata gula reduksi (\%) gula merah tebu akibat penambahan natrium metabisulfit

\begin{tabular}{ccc}
\hline $\begin{array}{c}\text { Natrium metabisulfit } \\
(\mathrm{g} / \mathrm{l})\end{array}$ & $\begin{array}{c}\text { Rerata gula } \\
\text { reduksi }(\%)\end{array}$ & BNT 5\% \\
\hline 0,1 & $9,856^{\mathrm{c}}$ & \\
0,3 & $6,362^{\mathrm{a}}$ & 0,2324729 \\
0,5 & $6,637^{\mathrm{b}}$ & \\
\hline
\end{tabular}

\section{Total Padatan Tak Terlarut (Total Disoluble Solid/TDS)}

Pengaruh perlakuan penambahan natrium metabisulfit dan suhu pemasakan terhadap TDS gula merah tebu terdapat pada Gambar 7.

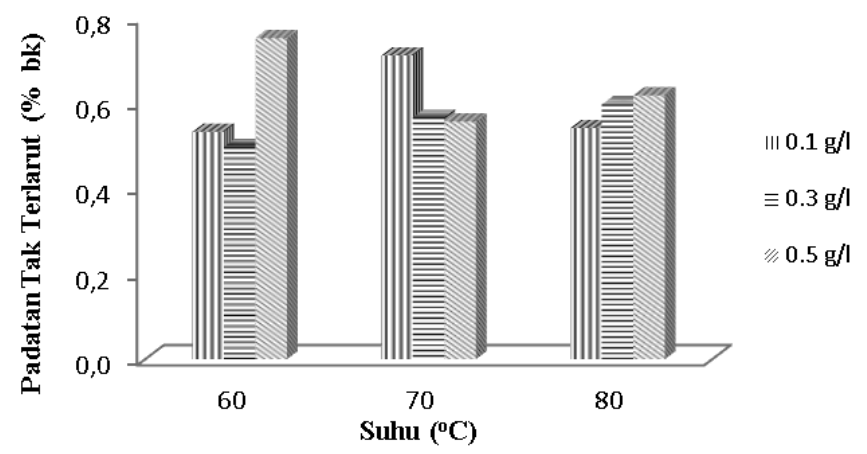

Gambar 7. Total padatan tak terlarut gula merah tebu pada variasi penambahan natrium metabisulfit dan suhu pemasakan

Total padatan tak terlarut menggambarkan keseluruhan bahan-bahan organik dan anorganik yang terkandung di dalam suatu cairan. TDS tidak mengindikasikan adanya polutan dalam suatu bahan, tetapi lebih digunakan untuk mengindikasikan nilai estetika bahan tersebut serta sebagai indikator adanya kontaminan kimia. Pada Gambar 7 dapat dilihat bahwa TDS terendah sebesar $0,5 \%$ pada penambahan natrium metabisulfit $0,3 \mathrm{~g} /$ liter pada suhu $60^{\circ} \mathrm{C}$. Sedangkan
TDS tertinggi sebesar $0,75 \%$ dengan penambahan natrium metabisulfit 0,5 gram/liter pada suhu $60^{\circ} \mathrm{C}$. Kandungan TDS yang rendah dapat dicapai karena dilakukannya proses penyaringan sebelum proses pemasakan. Semakin kecil jumlah kotoran nira hasil penyaringan maka semakin rendah total padatan tak terlarut. Hasil penelitian menunjukkan bahwa TDS semua variasi perlakuan kurang dari 1\%. TDS pada gula merah tebu telah sesuai dengan SNI 01-6237-2000 mutu I yaitu TDS maksimal $1 \%$.

Berdasarkan laporan Yustiningsih (2006), pada salah satu industri gula merah, penyaringan dilakukan sebelum dan sesudah pemasakan. Penyaringan setelah pemasakan bertujuan untuk menghilangkan kotoran yang berasal dari wajan pemasakan. Penyaringan tersebut menghasilkan gula dengan nilai TDS rendah.

Berdasarkan hasil analisis ragam menunjukkan bahwa faktor perlakuan suhu tidak berbeda nyata terhadap total padatan tak terlarut. Sedangkan faktor penambahan natrium metabisulfit memberikan pengaruh yang nyata terhadap TDS. Oleh karena itu, faktor ini dilakukan pengujian dengan BNT $5 \%$. Rerata nilai total padatan tak terlarut hasil dari BNT dapat dilihat pada Tabel 6 .

Tabel 6. Rerata TDS (\%) gula merah tebu akibat penambahan natrium metabisulfit

\begin{tabular}{lll}
\hline Natrium metabisulfit (g/l) & Rerata TDS (\%) & BNT 5 \% \\
\hline 0,1 & $0,534^{\mathrm{a}}$ & \\
0,3 & $0,497^{\mathrm{a}}$ & 0,0737186 \\
0,5 & $0,580^{\mathrm{ab}}$ & \\
\hline
\end{tabular}

\section{Uji Warna}

Dalam penelitian ini, uji warna dilakukan dengan menggunakan color analyzer yang bermodelkan RGB (red, green, dan blue). Data pengamatan uji warna pada masingmasing variasi perlakuan, dapat dilihat pada Tabel 7 .

Tabel 7. Indeks warna gula merah tebu

\begin{tabular}{|c|c|c|c|c|c|c|}
\hline \multirow{2}{*}{$\begin{array}{l}\text { Penambahan natrium } \\
\text { metabisulfit }(\mathrm{g} / \mathrm{l})\end{array}$} & \multirow{2}{*}{ Suhu $\left({ }^{\circ} \mathrm{C}\right)$} & \multirow{2}{*}{$\begin{array}{c}\text { Brix akhir } \\
\text { evaporasi (\%) }\end{array}$} & \multirow{2}{*}{$\begin{array}{l}\text { Waktu pemasakan } \\
\text { (menit) }\end{array}$} & \multicolumn{3}{|c|}{ Warna } \\
\hline & & & & $\mathrm{R}$ & $\mathrm{G}$ & $\mathrm{B}$ \\
\hline 0,1 & 60 & 81 & 130 & 314 & 134 & 96 \\
\hline 0,1 & 70 & 75 & 144 & 257 & 105 & 75 \\
\hline 0,1 & 80 & 84 & 133 & 203 & 87 & 68 \\
\hline 0,3 & 60 & 87 & 105 & 222 & 95 & 67 \\
\hline 0,3 & 70 & 75 & 93 & 326 & 130 & 87 \\
\hline 0,3 & 80 & 75 & 94 & 233 & 103 & 77 \\
\hline 0,5 & 60 & 75 & 99 & 221 & 94 & 63 \\
\hline 0,5 & 70 & 75 & 94 & 218 & 96 & 69 \\
\hline 0,5 & 80 & 72 & 93 & 86 & 119 & 81 \\
\hline
\end{tabular}


Pada gula merah tebu, nilai $R$ lebih tinggi daripada $G$ dan $\mathrm{B}$, sehingga di dalam gula merah tersebut lebih banyak terkandung warna merah daripada hijau maupun biru. Penambahan natrium metabisulfit memberikan pengaruh terhadap kecerahan warna gula. Hal ini dikarenakan penambahan natrium metabisulfit digunakan sebagai penghambat reaksi pencoklatan, baik reaksi maillard maupun karamelisasi. Semakin besar penambahan natrium metabisulfit, semakin rendah intensitas warna merah dalam gula merah tebu.

Saloko dan Lalu (2009), melakukan uji warna terhadap gula semut aren menggunakan teknik penguapan hampa. Faktor suhu dan lama evaporasi memberi pengaruh beda nyata terhadap warna. Evaporasi semakin lama menunjukkan brix akhir evaporasi semakin tinggi. Pada penelitian Wulandari (2011) disebutkan bahwa faktor brix di akhir evaporasi memberikan pengaruh nyata terhadap warna gula semut yang dihasilkan. Pengaruh dari faktor lama evaporasi sesuai dengan penelitian ini, yakni faktor brix di akhir evaporasi mempengaruhi warna gula merah tebu yang dihasilkan.

\section{Uji Organoleptik}

Hasil uji organoleptik gula merah tebu yang meliputi warna, rasa dan tekstur terdapat pada Gambar 8. Gula merah tebu dengan perlakuan penambahan natrium metabisulfit 0,3 $\mathrm{g} / \mathrm{l}$ dan suhu pemasakan $80^{\circ} \mathrm{C}$ lebih besar tingkat kesukaannya untuk warna daripada variasi perlakuan yang lain. Menurut Soediro (1982), warna gula cenderung menjadi coklat tua karena adanya zat-zat warna klorofil, anthosianin, xanthofil dan karoten pada nira, serta hasil penguraian gula pada proses pengolahan. Semakin besar penambahan natrium metabisulfit semakin cerah warna gula merah tebu. Selain itu, selama pengolahan gula merah tebu, peneliti menggunakan pengontrolan suhu dan pengadukan sehingga karamelisasi dapat dicegah. Akan tetapi batas penggunaan natrium metabisulfit dalam bahan pangan yaitu bahan pangan sekitar $2 \mathrm{~g} / \mathrm{kg}$ bahan pangan (Margono dkk., 2000). Sedangkan berdasarkan peraturan BPOM (2013) menyatakan bahwa
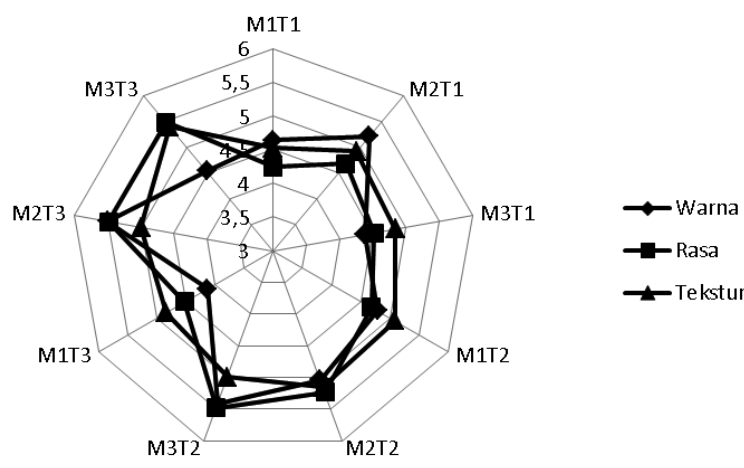

Gambar 8. Hasil uji organleptik gula merah tebu batas maksimum kalium bisulfit (yang diasumsikan sama dengan natrium metabisulfit) dalam gula merah sebesar 40 $\mathrm{mg} / \mathrm{kg}$.

Perlakuan suhu pemasakan $80^{\circ} \mathrm{C}$, penambahan natrium metabisulfit 0,3 g/l dan 0,5 g/l lebih besar tingkat kesukaannya untuk rasa daripada variasi perlakuan yang lain. Suhu pemasakan $80^{\circ} \mathrm{C}$ memiliki nilai lebih tinggi daripada suhu $60^{\circ} \mathrm{C}$ dan $70^{\circ} \mathrm{C}$. Hal ini dikarenakan suhu $80^{\circ} \mathrm{C}$ merupakan suhu optimal pemasakan yang menimbulkan reaksi karamelisasi yang tepat dan tidak berlebihan sehingga menghasilkan rasa khas karamel gula merah tebu. Oleh De Man (1997) dikatakan bahwa reaksi pencoklatan non enzimatis seperti reaksi maillard dapat mempengaruhi rasa.

Uji organoleptik untuk tekstur, perlakuan penambahan natrium metabisulfit $0,5 \mathrm{~g} / 1$ dan suhu pemasakan $80^{\circ} \mathrm{C}$ lebih besar tingkat kesukaannya daripada variasi perlakuan yang lain. Hal ini berkaitan dengan kadar air gula merah tebu dengan suhu pemasakan $80^{\circ} \mathrm{C}$ lebih rendah daripada suhu $60^{\circ} \mathrm{C}$ dan $70^{\circ} \mathrm{C}$. Hasil uji kekerasan gula merah tebu semakin menurun seiring rendahnya suhu pemasakan yang digunakan. Hal ini dapat dilihat dari nilai panelis yang semakin menurun. Selain itu, rendahnya nilai pada gula merah tebu dengan suhu rendah disebabkan karena sedikitnya penguapan yang terjadi sehingga mengakibatkan produk menjadi lunak atau tidak keras. Semakin kecil suhu pemasakan yang digunakan, semakin menurun kekerasan gula merah tebu.

\section{Pemilihan Perlakuan Terbaik}

Pemilihan perlakuan terbaik dengan metode De Garmo (1984) dilakukan dengan membandingkan parameter parameter dari setiap perlakuan. Hasil perhitungan seluruh produk disajikan dalam Tabel 8.

Tabel 8. Hasil perhitungan nilai produk setiap perlakuan

\begin{tabular}{ccl}
\hline $\begin{array}{c}\text { Natrium metabisulfit } \\
(\mathrm{g} / \mathrm{l})\end{array}$ & $\begin{array}{c}\text { Suhu pemasakan } \\
\left({ }^{\circ} \mathrm{C}\right)\end{array}$ & $\begin{array}{l}\text { Total nilai } \\
\text { perhitungan }\end{array}$ \\
\hline \multirow{2}{*}{0,1} & 60 & $-0,190$ \\
& 70 & 0,069 \\
0,3 & 80 & $-0,166$ \\
\hline \multirow{2}{*}{0,5} & 60 & $-0,054$ \\
& 70 & 0,064 \\
& 80 & $0,217 * *$ \\
\hline \multirow{2}{*}{0,5} & 60 & $-0,181$ \\
& 70 & 0,211 \\
& 80 & 0,135 \\
\hline
\end{tabular}

Keterangan : ** menunjukkan perlakuan terbaik

Tabel 8 menunjukkan bahwa perlakuan terbaik diperoleh pada produk dengan perlakuan penambahan natrium metabisulfit $0,3 \mathrm{~g} / \mathrm{l}$ dan suhu pemasakan $80^{\circ} \mathrm{C}$ dengan 
nilai masing-masing parameternya sebagai berikut: parameter kimia dan fisik dengankadar air 8,97 \%, gula reduksi 8,29 $\%$, kadar abu $0,96 \%$, total padatan tak larut $0,50 \%$, nilai kekerasan $15,68 \mathrm{~kg} / \mathrm{cm}^{2}$, parameter organoleptik dengan warna 5,50, rasa 5,04 dan tekstur 5,36. Secara organoleptik, produk gula merah tebu dengan perlakuan penambahan natrium metabisulfit $0,3 \mathrm{~g} / \mathrm{l}$ dan suhu pemasakan $80^{\circ} \mathrm{C}$ paling diterima oleh panelis terutama warnanya, yang memiliki nilai tertinggi dibandingkan dengan sifat kimia, fisik dan organoleptik lainnya. Perlakuan terbaik ini juga sesuai dengan persyaratan SNI gula merah tebu.

\section{KESIMPULAN}

Semakin tinggi suhu pemasakan maka semakin rendah kadar air, kadar abu, intensitas warna hijau dan biru gula merah tebu sedangkan tingkat kekerasan atau tekstur, tingkat kesukaan warna, rasa dan tekstur gula merah tebu semakin tinggi. Faktor suhu pemasakan memberikan pengaruh yang nyata terhadap kadar air, kadar abu, gula reduksi gula merah tebu yang dihasilkan. Semakin besar penambahan natrium metabisulfit dalam pengolahan gula merah tebu, semakin besar kadar abu yang dihasilkan sedangkan intensitas warna hijau dan biru gula merah tebu semakin rendah. Faktor penambahan natrium metabisulfit tidak memberikan pengaruh yang nyata terhadap kadar air gula merah tebu yang dihasilkan tetapi memberikan pengaruh yang sangat nyata terhadap kadar abu, gula reduksi dan TDS gula merah tebu yang dihasilkan. Berdasarkan parameter kualitas dan persyaratan SNI, penambahan natrium metabisulfit $0,3 \mathrm{~g} / 1$ dan suhu pemasakan $80^{\circ} \mathrm{C}$ dalam pengolahan nira tebu menjadi gula merah menunjukkan kualitas yang paling baik.

\section{DAFTAR PUSTAKA}

AOAC. (1995). Official Methods of Analysis of The Association of Official Agricultural Chemist. Washington D.C.

Badan Standarisasi Nasional (1992a). Cara Uji Makanan dan Minuman SNI 01-2891-1992. Badan Standarisasi Nasional. Jakarta.

Badan Standarisasi Nasional. (1992b). Cara Uji Gula SNI 012892-1992. Badan Standarisasi Nasional. Jakarta.

Badan Pengawasan Obat dan Makanan (2013). Batas maksimum penggunaan bahan tambahan pangan pengawet, peraturan kepala Badan Pengawas Obat dan Makanan, Indonesia, 2013. http://www.jdih.pom.go.id. [25 November 2013].

Darma, R., Tenriawaru, N., dan Sallatu, A. (2012). Integrasi gula merah tebu dan ternak sapi sebagai penggerak ekonomi pedesaan. http://www.repository.unhas.ac.id. go.id. [13 Maret 2014].

De Man, J.M. (1997). Principle of Food Chemistry. The AVI Publishing Company, Inc., Westport, Connecticut.

Dyanti (2002). Studi Komparatif Gula Merah Kelapa dan Gula Merah Aren. Skripsi. Jurusan Teknologi Pangan dan Gizi. Fakultas Teknologi Pertanian. Institut Pertanian Bogor, Bogor.

Firmansyah, R.W. (1992). Mempelajari Pengaruh Penambahan Bahan Pegawet terhadap Umur Simpan Nira Siwalan (Borassus flaberifera Linn.) serta Mutu Gula Merah, Gula Semut dan Sirup yang Dihasilkan. Skripsi. Fakultas Teknologi Pertanian. Institut Pertanian Bogor, Bogor.

Kementerian Pertanian (2013). Kebutuhan gula nasional, 2013. http://www.ditjenbun.deptan.go.id. [25 November 2013].

Kementerian Pertanian (2013). Survey sosial ekonomi nasional 2007-2013, 2013. http://www.pertanian.go.id. [1 Januari 2014].

Lesthari, A.P. (2006). Pengaruh Waktu Tunda Giling Tebu dan Penambahan Natrium Metabisulfit terhadap Mutu Gula Merah Tebu. Fakultas Teknologi Pertanian, Institut Pertanian Bogor, Bogor.

Margono, T., Suryati, D. dan Hartinah, S. (2000). Pengawetan dan bahan kimia. http://www.warintek.ristek.go.id/ pangan/umum/pengawetan.pdf. [10 Juli 2013].

Narulita, R.R. (2008). Peningkatan Mutu Gula Merah Tebu Melalui Penerapan Teknologi Pemasakan Sistem Uap (Studi Kasus di Kabupaten Rembang, Jawa Tengah). Laporan Penelitian. Fakultas Teknologi Pertanian. Institut Pertanian Bogor, Bogor.

Nurlela, E. (2002). Kajian Faktor yang Mempengaruhi Pembentukan Warna Gula Merah. Skripsi. Departemen Ilmu dan Teknologi Pangan. Institut Pertanian Bogor, Bogor.

Rakhmadiono, S. (1995). Pengolahan Kelapa (Studi Kasus Pengolahan Gula Kelapa di Desa Sawentar Kecamatan Kanigoro Kabupaten Blitar). Fakultas Pertanian. Universitas Brawijaya, Malang.

Saloko, S. dan Lalu, I. (2009). Pembuatan gula semut aren menggunakan teknik penguapan hampa. Seminar Nasional dan gelar Teknologi Perhimpunan Teknik Pertanian Indonesia. AI. 81-89.

Soediro, S. (1982). Pengolahan Gula Merah Kristal dari Tebu (Saccharum officinarum) di Desa Slumbung Kecamatan Ngadiluwih Kabupaten Kediri Jawa Timur. Skripsi. 
Fakultas Teknologi Pertanian. Universitas Gadjah Mada, Yogyakarta.

Standar Nasional Indonesia (1995). Gula Palma (SNI 013743-1995). Pusat Standarisasi Industri. Departemen Perindustrian, Jakarta.

Standar Nasional Indonesia (2000). Gula Merah (SNI 016237-1995). Pusat Standarisasi Industri. Departemen Perindustrian, Jakarta.

Sudarmadji, S., Haryono, B. dan Suhardi. (1989). Analisa Bahan Makanan dan Pertanian. Penerbit Liberty, Yogyakarta.
Wulandari, E.Y. (2011). Model Matematis Perubahan Sifat Fisik selama Proses Pengolahan Gula Semut dengan Melakukan Penetapan Brix pada Akhir Evaporasi. Tesis. Fakultas Teknologi Pertanian. Universitas Gadjah Mada, Yogyakarta.

Yustiningsih, F. (2006). Perbaikan Proses Penjernihan Nira Tebu pada Industri Gula Merah (Studi Kasus pada Industri Gula Merah Tebu di Kecamatan Kebonsari, Kabupaten Madiun). Fakultas Teknologi Pertanian. Institut Pertanian Bogor. Bogor. 